\title{
Chapter 9 \\ Seafarers and Arctic Cruise Shipping: \\ Protecting Those Who Work While Others Explore and Sightsee
}

\author{
Joseph Anthony Loot
}

\begin{abstract}
Arctic cruise shipping is a growing niche in the highly globalized cruise shipping industry. The service workers in the hotel operations of expedition cruise ships are beneficiaries of Arctic cruise tourism. They provide leisure, tourism, travel, and hospitality services to the increasing number of international cruisers who are motivated to experience the "last frontier" tourism, including the changing and disappearing Arctic landscape and wildlife. The Maritime Labour Convention, 2006 considers these service workers as seafarers and ensures the protection of their rights to decent work and living standards.

The global cruise shipping industry operates within an international market system governed by the neoliberal policies of privatization, liberalization, and deregulation. The neoliberal market system creates an imbalance in the power relations in favour of corporations over the state. There are three actors with contending interests that operate the global cruise shipping industry: states, shipowners, and seafarers. Considering the contentious tripartite relations, the neoliberal globalization of the industry moves shipowners to register their ships in flags of convenience and gain access to cheap seafarer labour, labelled as "crew of convenience" on the global seafarer labour market. The treatment of seafarers as "crew of convenience" is a labour and human rights concern. Nevertheless, there are international standards that protect the labour and human rights of seafarers. Mechanisms to implement these standards exist for the three industry parties to use. The mechanisms reconcile the contending interests, address the problems of globalization, and serve as a framework for research.
\end{abstract}

Keywords Arctic cruise shipping - Arctic cruise tourism · Global cruise shipping industry $\cdot$ Expedition cruise shipping $\cdot$ Neoliberal globalization $\cdot$ Flag of convenience $\cdot$ Cruise ship service workers $\cdot$ Crew of convenience $\cdot$ International labour standards $\cdot$ International human rights $\cdot$ Tripartite industry relations

\footnotetext{
J. A. Loot $(\bowtie)$

Interdisciplinary PhD Program, Dalhousie University, Halifax, Canada

e-mail: jloot@dal.ca
} 


\subsection{Invisible Beneficiaries}

Environmental changes are making the navigable waters in the Canadian Arctic archipelago accessible to international shipping and simultaneously opening economic opportunities for people external to the region. One cohort of people are the seafarers who work on commercial passenger vessels engaged in Arctic cruise tourism. These seafarers are the invisible workers on board the expedition cruise ships, and they benefit through their employment from the tourism activities in the Arctic. As the expedition cruise traffic in the Canadian Arctic continues to dramatically increase with more travel routes and destinations becoming viable for exploration and sightseeing (Manley et al. 2017; Lajeunesse 2012; Dawson 2018), more seafarers will be recruited to serve the growing number of cruising passengers.

The seafarers, particularly those working in the hotel section of cruise ships, comprise a distinct but essential and invisible group ${ }^{1}$ of workers who contribute to the growth of the broader tourism, travel, leisure, and hospitality industries. They are a significant component of the service supply chain that supports the growth of the expedition cruise shipping's niche in the Arctic tourism market (Véronneau and Roy 2009). This industry growth is advantageous to Canada's economic development and contributes to the on-going increase in the larger and highly global cruise shipping industry (Dawson 2018; Innovation, Science and Economic Development Canada 2018).

Despite their contributions to the cruise shipping industry revenue and state national income, the seafarers providing the services in the different types of cruise ships are discriminated, exploited, and abused. In the same manner as the seafarers in the marine section of cruise ships, the service workers are treated as "crew of convenience." This treatment is the result of the neoliberal policies governing international shipping and the contentious relations between the three actors - the state, shipowners, and seafarers - that operate the global industry (Dimitrova and Blanpain 2010). To address this labour concern, the United Nations maritime, labour, and human rights organizations enacted international standards aimed at protecting the employment and social rights of all seafarers in all segments or sectors of international shipping. There are various mechanisms available for the industry actors to implement these standards. These mechanisms ensure the protection of the rights of seafarers and enable these workers to act on their rights.

This chapter presents theoretical propositions on the protection of the rights of seafarers working in the global cruise shipping industry. The focus of discussion is on the protection of the rights of the seafarers who provide the tourism and hospitality services in the hotel operation of cruise ships, particularly in those vessels

\footnotetext{
${ }^{1}$ Seafarers are the invisible workers who operate both the marine and hotel functions of cruise ships. They live and work on ships that most of the time are at sea and away from shore. Their living and working places on board the ship are not easily accessible to people. Passengers may have access to go on board, but only on limited unrestricted spaces and only during the duration of travel. Moreover, the overall living and working conditions of seafarers on board are hidden from public view and scrutiny.
} 
engaging in Arctic expeditions. These service workers comprise the non-traditional seafarers who are not trained and certificated in safe and efficient vessel navigation, but they directly engage with the passengers for whom the safe and experiential expedition cruises are designed. However, they are trained in specific hotel operation services, including providing safety assistance during emergencies. The sequence of discussion centres on three points. The first point describes the growth of Arctic expedition cruise shipping as a segment of the growing and globalized cruise shipping industry. Second, an examination of the labour and social conditions of employment on board the cruise ships raises the need for protection of the rights of seafarers. Third, there are existing international maritime labour standards and implementation mechanisms that protect the rights of seafarers and provide these workers with the means to protect their rights.

\subsection{Expedition Cruise Shipping}

An expedition cruise is a form of ecotourism activity on board specially designed small expeditionary ships operated by specialized companies that offer an exclusive educational experience to a small group of passengers-customers-tourists (Walker and Moscardo 2006; Faber and Saltzman 2019). Expedition cruising is closely related to adventure cruising in terms of small ship size, low number of passengers and crew, and remote destinations intended for exploration and adventure. However, the key distinction is the learning experience in expedition cruising through educational activities (onboard lectures, on-site tours and guided walks, snorkelling and diving, zodiac boat trips in areas inaccessible by ship, and wildlife/scenery photography) conducted by an expedition team comprising natural and social scientists who are experienced in the various settings (ecology, culture, geography, anthropology, politics, biology, among others) of the destination (Smith 2006).

Expedition cruise shipping in the Arctic is a rapidly expanding industry. Although a small segment with just less than $1 \%$ of the global cruise market (Jarvis 2017), the expedition cruise market will experience a 4-year boom between 2019 and 2023 according to the 2019 Expedition Market Report published by the Cruise Industry News. The highlights of this growth are:

- 41 new generation expedition ships with strong ice-class hulls and longer fuel and provision space are set to be delivered to 17 cruise operators.

- Introduction of over 8500 berths that are projected to double the 2018 capacity.

- Potential growth of four to five dozen ships and their market entry within 6 years.

- Smaller ships with an average orderbook size of 214 guests.

- Established players and new market entrants expected to contribute to the projected number of new ships.

- Antarctica and the Arctic as new frontiers for niche and luxury cruise brands in order for tour operators to keep their customer base of affluent cruisers (Mathisen 2019). 
Smaller ships built for rough operating environments are considered more rewarding for cruisers given their flexibility in reaching remote areas that allow more shore landings. After two voyages of the 1000-passenger non-ice-class cruise ship Crystal Serenity through Canada's Northwest Passage in 2016 and 2017, Crystal Cruises is shifting to a smaller 100-guest purpose-built Polar-Code compliant megayacht by 2020 (The Maritime Executive 2017). This shift in ship size is indicative of the growth prospects of expedition cruises in Canada's Arctic. The small size expedition cruise ships that sailed the Northwest Passage in 2019 include the RCGS Resolute (146-passenger capacity), Ocean Endeavour (198), Ocean Adventurer (215), Silver Cloud (240), L'Austral (264), MS Fram (317), and MS Roald Amundsen (500).

Another aspect of the growth prospect that supports the increase in the number of ships is the consumer demand for the distinct expeditionary experience in the Arctic. Demand is created by two interrelated factors: the innovative marketing of tour operators and the change in cruiser motivation. Both tour operators and cruisers share an interest in the new niche tourism market labelled as the "last chance" or "last frontier" tourism, which refers to the Arctic as a tourism destination with its unique and iconic but changing and disappearing landscape and wildlife (Dawson et al. 2014; Dawson 2018). Thus, tour operators are building business portfolios and developing programs that include ice-class vessels, new year-round itineraries, and luxury expedition cruising (Mathisen 2019). Further, the increasing accessibility to geographically remote areas due to the decline of sea ice and the availability of icestrengthened vessels enhance the motivation of the growing base of affluent and retired baby boomers to experience and learn the novelty of the Arctic landscape, particularly in Canada (Dawson et al. 2014; Manley et al. 2017).

The growth in the number of expedition cruise ships implies an increase in the number of staff and crew who will provide the services of the ship's hotel operation. The small ship size explains the fact that expedition cruise ships do not have the resort amenities and services of the larger cruise ships. The essentials on board a polar expedition cruise include the luxury passenger cabins and suites, lounging and dining rooms (separate from cabin and suite services), exercise rooms, library with a significant collection of polar books, ship-to-shore communication room, boutique, and multi-purpose presentation room. The services to maintain and operate these amenities and attend to passenger needs are performed by the ship's service crew 24 h every day throughout a cruise itinerary (between 2 and 3 weeks, mainly during the summer cruise season). Generally, the service ratio (crew-passenger) onboard is low (e.g., MS Fram capacity is 318 passengers and 75 crew) to enable a complete, personalized, distinctive, and high-quality service that reflects the luxury of an expedition cruise.

Despite the unique experience offered by expedition cruises in the Arctic, there are risks to navigation in the region. Two expedition cruise ships ran aground while cruising through Canada's Arctic: the Clipper Adventurer in 2010 and the Akademik Ioffe in 2018. The passengers and crew of both ships were rescued and evacuated. During maritime accidents and in the rescue and evacuation procedures, the cruise 
ship's trained service crew is required to provide the extended assistance of ensuring passenger safety.

\subsection{A Global Industry}

The various shipping sectors of international shipping have the characteristics indicating the global condition of the industry. The following characteristics are common to all the sectors, especially cruise shipping and its different segments:

- High vessel mobility through non-territorial spaces and cross jurisdictions (DeSombre 2006).

- Maritime operations in a complex system of worldwide shipping networks of ports and navigational routes (maribus gGmbH 2010).

- International demand for maritime transport and the consequent technological advancement to increase cargo tonnage and enhance travel and migration of people to international destinations (Williams and Armstrong 2010).

- Shipping operations occurring in a global free-market system that is governed by the neoliberal policies of privatization, liberalization, and deregulation.

- Registration of ships in open and second registers located away from national control.

- Multinational ownership and management of ships, regulatory control, and crew composition.

Compared with the other sectors of shipping that are engaged in global trade and operation, cruise shipping is the most globalized (Terry 2011; Weaver and Duval 2008). Cruise ship technology steadily improves (size, carrying capacity, facilities, and amenities), and ship deployment and tourism destination and itineraries increase. The cruise shipping sector operates within a market-driven global port system (Rodrigue and Notteboom 2013), transnational flagging and management practices of shipowners (Chin 2008a; Wood 2000), and the multinational crewing of ships by transnational shipping companies (Chin 2008a; Gibson 2008). Cruise ships, in particular, are floating resorts and deterritorialized touristic destinations of multinational clientele who converge on board the vessel and in geographical areas that are detached from the passengers' communities and countries (Chin 2008a; Wind Rose Network n.d.).

The global characteristics of cruise shipping exist in the smaller expedition cruise segment. As an example, the Crystal Serenity, which cruises in various international destinations, is legally owned and managed in the United States by two corporations (Serenity Holdings Inc. and Crystal Cruises LLC, respectively), is beneficially owned in China (Genting Hong Kong Ltd. 2015), is flagged in the Bahamas, and is manned by Asian, European, and North American officers and crew (Equasis 2019a; Genting 2015). Another expedition ship that frequents the Northwest Passage, MS Fram, cruises in the Arctic and Antarctica, and is owned and managed 
by the Norwegian Hurtigruten Cruise AS, is flagged in Norway, and is manned by Norwegian and Filipino officers and crew (Equasis 2019b).

In addition to its international reach, cruise shipping operates within an international market governed by neoliberal policies. Neoliberalism is the dominant ideology in the process of globalization. It is built around two core ideas: (1) the superiority of the market and the efficacy of market mechanisms in allocating resources and (2) the distrust with governments in intruding into economic affairs, thereby allowing the shift of power to market forces through policies of deregulation, privatization, and market competition (Wood 2006; Harvey 2005; Bowles 2008). When the neoliberal ideology is translated into a policy doctrine, marketbased economic growth processes are accelerated through technological advances and the policies of privatization, liberalization, and deregulation (Scholte 2005). The market-based growth processes are working in the cruise shipping industry as demonstrated by the advancements in ship technology, industry-led productivity, the cross-border movement of cruise ships, and the regulatory limitations on government interference in the market dynamics and efficacy of cruise ship operations. The regulatory limitations on government authority are manifest in the unrestricted ship registration practices and the flexibility of the seafarer labour market.

\subsection{Tripartite Labour Relations}

Within the industrial relations system, there are three principal actors with individual interests expressed through specific means to achieve specific goals (Bellemare 2000). In the tripartite system of the International Labour Organization (ILO), these actors are represented by employers' organizations, workers' organizations, and member states (ILO n.d.-a). In the cruise shipping industry, there are three primary actors with specific interests: the seafarers who seek to protect their economic and social rights, the shipowners who pursue the advancement of capital, and states that seek to balance human rights and market gains.

With the neoliberal globalization of world markets today, the focus is on multinational corporations (MNCs) or transnational corporations (TNCs) because of the impact of the power they possess on human rights conditions and state action. As global actors, TNCs wield significant power to the extent that corporate financial investments influence critical state's actions: relax its monitoring of corporate behaviour; use corporate resources in abusing human rights; and lose control in implementing regulations (Ratner 2001). With the state retreating in the face of the advances of corporations, this imbalance gives the power of capital the advantage to seek labour and use it to maximize economic self-interest at the expense of human rights (Strange 1996). While TNCs indeed create jobs, bring in fresh capital and new technology, and provide employees with health care, they actually exploit workers, particularly those from the global South, by placing them in sweatshops characterized by low pay, hazardous working conditions, absence or limited 
fundamental worker rights and benefits, and racial discrimination (Ratner 2001; Wood 2006; Chin 2008a; Terry 2011).

The power imbalance between the actors and its negative impact on the protection of workers' rights exist in the cruise shipping industry. The practice of ship registration and the treatment of seafarer labour across the various segments of cruise shipping show the influence of shipowners on state action and seafarer employment and social well-being.

\subsection{The Global Seafarer and the "Crew of Convenience"}

A "seafarer" as defined in Article II, paragraph 1(f) of the Maritime Labour Convention, 2006 refers to "all persons who are employed or are engaged or work in any capacity on board a ship to which the Convention applies." This definition includes the crew who navigate or operate the ship and the personnel who provide the services in the hotel section of the ship. In cases of doubt as to whether a category of workers shall be regarded as "seafarer" covered by the Convention, the national competent authority must make a determination on the question in consultation with the shipowners' and seafarers' organizations (Article II, paragraph 3).

There are two types of seafarers working in two separate operations on board a cruise ship: the traditional seafarers who navigate and operate the ship and the service workers who provide the leisure, tourism, travel, and hospitality services as part of the hotel operations of cruise ships. Unlike the traditional seafarers who are required to complete rigid maritime education, training, and certification for employment, the service workers' basic qualifications for work on cruise ships are skills-based for entry-level positions and work-related experience for higher-level positions in the various hotel departments. An additional employment requirement for service workers is the completion of cruise ship safety training before joining a ship.

Cruise ship crew composition is highly diverse in terms of nationality, racial origin, gender, and culture-a "mini-United Nations" - on board a large modern sailing vessel (Chin 2008a). On the smaller expedition cruise ships, the diversity is less intense. However, diversity is more intense in the hotel section of the cruise ship than the marine section. There are more varieties of hotel operation services performed by the crew from various nationalities. The presence of diversity, regardless of intensity, reflects the flexibility of maritime labour in favour of capital, a consequence of the application of the neoliberal policy of deregulation (Chin 2008a). The unregulated practice by cruise shipowners and operators of employing seafarers from different countries is in response to market conditions and aims at boosting customer service and corporate profit.

The neoliberal globalization of the cruise shipping industry moves shipowners and managers to register their ships in open registers, commonly labelled as flags of 
convenience or FOCs, ${ }^{2}$ in order to gain access to cheap seafarer labour, a "crew of convenience," on the global seafarer labour market. FOCs offer minimal restrictions on seafarer's nationality, pay, and working conditions. As a result, shipowners and operators employ seafarers from less developed countries who are willing to accept low contract compensation and work in inferior and exploitative conditions (Alderton and Winchester 2002; Dimitrova and Blanpain 2010). These seafarers are oftentimes subjected to expensive third-party recruitment requirements, discriminated against on the basis of nationality, gender, and race, contracted to work for specific periods with no guarantee for continued and future employment opportunities, provided with limited access to communication and information, provided with inconvenient accommodation, required to work long hours without a vacation or day off, and denied access to full health protection (Chin 2008b). The Bahamas is a FOC where expedition cruise ships such as the Ocean Adventurer and Ocean Endeavour are registered (ITF n.d.; Equasis 2019c; Equasis 2019d).

Maintaining the practice of FOCs, nonetheless, has significant economic benefits to the cruise shipowners, the FOC and labour supplying state, and the seafarer. Shipowners incur lower operating costs through the liberal conditions, which include minimal regulation, cheap registration fees, low or no taxes, and freedom to employ cheap labour from the global labour market (Tolofari et al. 1986). For states, the FOC practice is a source of national income through either ship registration or labour export, respectively. Also, for the labour supplying state, particularly developing countries, the export of seafarer labour fulfils the state obligation of providing employment, and seafarer remittances are essential revenue for domestic production and spending (Dimitrova and Blanpain 2010). As a crew of convenience, seafarers benefit from overseas employment that is not available in their home country. The reality is that seafarers endure the cost of exploitative employment on board the ship because of the assurance of the economic benefit that is far more difficult to acquire at home.

Considering the economic benefits of FOCs, an overriding question is: if the three industry actors benefit from the FOC and crew of convenience, how would an international maritime labour and human rights standard, and its implementation, protect the seafarers? There are at least two answers to the question. First, it is necessary to cushion the impact of FOC practice on seafarer well-being. Under the FOC system, seafarers are an easy target for extreme physical, economic, and social abuse by dishonest shipowners (Dimitrova and Blanpain 2010). Seafarers, particularly those coming from the global South, are placed in "sweatships" characterized by low pay, hazardous working conditions, absence or limited fundamental worker rights and benefits, and racial discrimination (Chin 2008b; Walker 2016). The ability of the seafarer to endure such abuse is limited and, thus, could lead to loss of employment and an income source. Second, the presence of regulatory standards

\footnotetext{
${ }^{2}$ The term "FOC" is used less today because of the stigma attached to the term (Mukherjee and Brownrigg 2013). However, the International Transport Workers' Federation continues to use the term and lists the countries that it has declared FOCs (International Transport Workers' Federation n.d.).
} 
will empower seafarers to act on their rights. The seafarer is the weakest in the tripartite relationship in terms of economic and political power. When shipowners advance through abuse and the state retreats on its obligation to protect labour and human rights, seafarers will be rendered unable to defend themselves.

\subsection{International Maritime Labour Standards}

There are three interconnected international legal standards on the protection of seafarers in the global maritime industry: the protection of seafarers' rights under the ILO conventions, the protection of human rights under the United Nations' (UN) human rights treaties, and the enhancement of maritime safety under the International Maritime Organization's (IMO) conventions. This set of interconnected legal guarantees establishes the integration of seafarers' rights and human rights and their comprehensive legal protection sanctioned by states. Seafarers have, under international law, human rights and fundamental freedoms that cannot be removed, overridden, or waived by contracts of employment (Seafarers' Rights International 2016).

The core treaty law on the protection of seafarers' rights is the Maritime Labour Convention 2006 (MLC 2006) that became binding on state parties on 20 August 2016, a year after the requirements for entry into force under Article VIII were fulfilled. An ILO maritime labour standard, MLC 2006 is an international "bill of rights of seafarers" and "a global response to a global problem" (McConnell et al. 2011). The MLC 2006 consolidated numerous ILO conventions and recommendations. Seafarers' rights are categorized into fundamental rights and principles (Article III) and seafarers' employment and social rights (Article IV); globalization and competition issues are addressed in the MLC 2006 with the goal of creating a "level playing field" to benefit stakeholders in the maritime community through fair competition (McConnell et al. 2011; Blanck Jr 2006). Designed as the fourth pillar of the international maritime regulatory regime, the MLC 2006 mainstreams maritime labour standards and compliance and enforcement, thereby complementing and completing the IMO's approach of developing and maintaining a comprehensive regulatory regime for quality shipping established in the three IMO core conventions on marine pollution, ship safety, and seafarer competency (Blanck Jr 2006) (see further below).

The human rights of seafarers are provided for in two human rights instruments of the United Nations: the 1948 Universal Declaration of Human Rights (UDHR) and the 1966 International Covenant on Economic, Social, and Cultural Rights (ICESCR). These two instruments proclaim the social and economic rights that workers are entitled to enjoy and set the standards of state behaviour in protecting human rights. The UDHR is "soft law," but its universalist foundation and the broader benefits from membership in this instrument, even under diminished or minimal obligation, are key reasons for states to sign the declaration (R.K. Smith 2009; Hathaway 2007). The UDHR provides the essential principles of equality 
(Section 1) and non-discrimination (Section 2) for the protection of the employment (Section 23) and social rights (Sections 22, 24, and 25) of seafarers. On the other hand, ICESCR is a binding covenant that identifies the "second generation" rights requiring state action for enforcement (Vasak 1977; van Boven 1982; Ssenyonjo 2009). The 2008 Optional Protocol to the Covenant on Economic, Social, and Economic Rights (OP-ICESCR) provides for an inter-state complaint mechanism and individual complaint procedure, and the Committee on Economic, Social and Cultural Rights (CESCR) monitors its implementation.

The regulatory standards for safety at sea set by the IMO do not create rights for seafarers since they cover only the technical aspects of maritime safety, navigation, equipment, training, certification procedures, and marine pollution, but they recognize the importance of the human element in maritime safety, security, and marine environmental protection (Seafarers' Rights International 2016; ChristodoulouVarotsi and Pentsov 2008; Dimitrova and Blanpain 2010). The three pertinent IMO international conventions are the International Convention on Standards of Training and Watchkeeping for Seafarers (STCW) 1978, the International Convention for Safety of Life at Sea, 1974 (SOLAS) and, under it, the International Safety Management Code (ISM Code) as amended, and the International Convention for the Prevention of Pollution from Ships, 1973 (MARPOL). These standards address the multidimensional issues that involve human activities and their effect on maritime safety and pollution prevention (IMO n.d.-a). The effective and consistent global implementation and enforcement of these conventions are covered in the IMO Instruments Implementation Code adopted in 2013, which enhanced the standards on maritime safety and security and protection of the marine environment through the review and identification of the rights and obligations of states and the implementation of the mandatory IMO audit scheme (IMO n.d.-b).

\subsection{Implementation Mechanisms}

Implementation and enforcement are often understood as synonymous and used interchangeably. However, the terms are distinct from each other. Implementation refers to the broad application of the law to improve policy and increase support for the improvement (Mazmanian and Sabatier 1989). It is one of the processes in the function and execution of policy or law (Satterlund et al. 2009). Enforcement, on the other hand, involves specific actions that include sanctions intended to compel compliance (Brunnée 2005). Distinguishing implementation from enforcement allows better contextualization of the specific processes related to the function and execution of policy.

Table 9.1 lists the various mechanisms available for shipping industry actors to implement maritime labour standards. The free online Black's Law Dictionary defines a mechanism as a component, an element, or a part that enables a process or system to achieve an intended result. From this definition, the list of mechanisms serves two purposes. First, it provides information about the 
Table 9.1 Mechanisms to implement maritime labour standards

\begin{tabular}{|c|c|c|c|c|c|}
\hline \multirow{2}{*}{\multicolumn{2}{|c|}{ Actors }} & \multicolumn{4}{|l|}{ Mechanisms } \\
\hline & & \multirow{2}{*}{$\begin{array}{l}\text { Organizational- } \\
\text { structural- } \\
\text { functional } \\
\text { International } \\
\text { multilateral } \\
\text { Regional } \\
\text { organizations } \\
\text { National } \\
\text { departments, } \\
\text { competent } \\
\text { authority }\end{array}$} & \multirow[b]{2}{*}{ 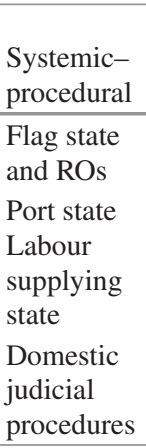 } & \multirow{2}{*}{$\begin{array}{l}\text { Social-political } \\
\text { Maritime } \\
\text { education and } \\
\text { training } \\
\text { Social dialogue }\end{array}$} & \multirow[t]{2}{*}{ Corporate } \\
\hline $\begin{array}{l}\text { Public- } \\
\text { traditional/ } \\
\text { Conventional }\end{array}$ & States & & & & \\
\hline \multirow[t]{3}{*}{$\begin{array}{l}\text { Private- } \\
\text { alternative }\end{array}$} & Seafarer & $\begin{array}{l}\text { Unions and } \\
\text { associations } \\
\text { Legislative } \\
\text { representation }\end{array}$ & $\begin{array}{l}\text { Domestic } \\
\text { judicial } \\
\text { remedies }\end{array}$ & Social dialogue & \\
\hline & Shipowner & $\begin{array}{l}\text { Shipping } \\
\text { associations }\end{array}$ & & Social dialogue & $\begin{array}{l}\text { CSR, } \\
\text { industry } \\
\text { self- } \\
\text { regulation }\end{array}$ \\
\hline & $\begin{array}{l}\text { Other actors } \\
\text { (public } \\
\text { interest } \\
\text { groups) }\end{array}$ & $\begin{array}{l}\text { International } \\
\text { NGOs, civil } \\
\text { society } \\
\text { organizations }\end{array}$ & & $\begin{array}{l}\text { Investigations, } \\
\text { research, } \\
\text { advocacy } \\
\text { Maritime } \\
\text { ministry }\end{array}$ & \\
\hline
\end{tabular}

strategies and activities relevant to policy formulation and reform. The mechanisms are drawn from the labour and human rights treaties and the practices of the actors involved in the operation of the general global shipping industry or a particular shipping sector (such as cruise shipping) and the smaller segments of the shipping sector (such as expedition shipping). Second, the list identifies specific actions that can lead to the reconciliation of the contending interests of industry actors, realize the protection of seafarers' rights, and empower seafarers to act on the protection of their rights. The mechanisms identified are aimed at addressing the labour problems arising from globalization, the contentious interests of the actors, and violations of the legally recognized rights of the seafarers.

\subsubsection{Organizational-Structural-Functional Mechanisms}

Organizational mechanisms are international and domestic organizations that engage in methods to ensure the observance of human rights established under existing laws (Vasak 1982). Organizations at the inter-state level are international 
governmental organizations (IGOs), which implement member state labour standards. Structurally, the link between the international organization and the state is a prerequisite for the former to successfully carry out its functions of implementing regulatory standards on the latter (Vasak 1982; Knudsen and Hassler 2011). Functionally, IGOs perform supervisory, monitoring, and information processing and reporting activities to ensure compliance of states with their treaty obligations and to allow workers' and employers' organizations and international NGOs (INGOs) to examine state compliance and pursue mechanisms for improvement in the application of international convention standards (ILO 2014). Private and voluntary non-state organizations (INGO and NGO) comprising individuals or their associations also contribute to the protection of human rights.

At the domestic level, the organizational mechanism includes national government departments and agencies, with their structures, functions, and interconnections a critical element in formulating laws and policies that implement the state's treaty obligations. The presence of workers and employers' associations complete the tripartite structure and function within the state. The tripartite system that functions at the international level is not a functional mechanism within the state in the absence of worker and/or employer representation.

\subsubsection{Systemic-Procedural Mechanisms}

Flag and port state responsibilities and jurisdictions are the primary systems of implementation under ILO's maritime labour and IMO's safety of navigation standards; labour supplying state responsibilities are an innovation in the MLC 2006 that highlight the state's important role in maintaining labour standards on seafarer recruitment, employment agreement, and social security (McConnell et al. 2011). Although the flag and/or port state may not be the home nation of a seafarer, the system and procedure of inspection and certification comprising the flag and port state responsibilities reinforce the measures adopted to regulate substandard ships, facilitate ships' timely port entry and exit, and improve the seafarers' bill of rights and the shipowners' ability to retain and recruit qualified seafarers amid existing global maritime labour market conditions (Lilie 2008; Blanck Jr 2006; Piniella et al. 2013), as well as complementing any shortcomings in the control measures of either the flag or port state (Christodoulou-Varotsi and Pentsov 2008). The onboard and onshore complaint mechanisms are additional complementary flag and port state inspection functions (Politakis 2013). The system of inspection, including monitoring and legal proceedings for breaches of MLC 2006 operational requirements, is particularly vital for the labour-supplying state because it links the state to the chain of responsibility to protect seafarers, especially those who are its nationals, resident, or domiciled in its territory (Christodoulou-Varotsi and Pentsov 2008; Lilie 2008).

States enter into regional arrangements for port state control (PSC) known as the port state control memorandum of understanding (PSC MOU) to address more effectively the concerns about sub-standard vessels and their danger to maritime 
safety. The arrangements also address the differences in the extent that port states apply their national laws. Fundamental to this cooperation is the application by port state authorities of a common and uniform set of laws and standards to vessels that visit the ports within a region (McDorman 2000). Structurally, a regional PSC MOU establishes a committee comprising representatives of the member state's national maritime administration and acts as the MOU's executive body. Such MOUs, however, have specific limitations, such as lack of binding effect, territorial jurisdiction, and authority to detain ships in the context of technical standards; however, these limitations do not hinder the function of MOUs in resolving the anomalies that clearly risk the safety and health of seafarers and in contributing to the realization of PSC (Christodoulou-Varotsi and Pentsov 2008; McDorman 2000).

Since the responsibility of implementing seafarer rights and human rights standards rests primarily with the state, the national legislative, judicial, and executive branches of government examine, formulate, revise, and adopt national legislation and policies in order to give effect to the standards in the treaties that a state ratifies. In the context of the law and policy formulation process under MLC 2006, government agencies are expected to produce consensus through the tripartite social dialogue system in order to bring legislative and policy frameworks closer to the international labour standards set by the maritime industry. Thus, in the development, promulgation, and review of domestic laws, the political branches of government are required to follow the consultative process. With regard to ICESCR, although the formulation of legislation is left to the legislature without mentioning specific procedures, the state is expected to comply with the obligation to take the appropriate steps to adopt legislative measures that include judicial remedies for the human rights that under the national legal system are considered justiciable. This gives the judiciary an essential role, and judicial remedies are necessary for the promotion of social and economic rights, especially of vulnerable groups that have minimal options to protect themselves. Arbitration is one accessible alternative judicial process accepted by the parties in a proceeding and encouraged by the judicial system as a tool to resolve maritime (including labour) disputes (Cortazzo Jr. 2012). Arbitration, whether voluntary or compulsory, is a dispute settlement procedure provided for in the ILO Voluntary Conciliation and Arbitration Recommendation, 1951 (No. 92) and may also be explicitly provided for in domestic legislation (ILO n.d.-b).

\subsubsection{Social-Political Mechanisms}

Socio-political activities comprise the third type of mechanism to implement maritime labour standards. Social dialogue, generally done in a tripartite arrangement, is common to the three industry actors. However, the ILO defines social dialogue as either a tripartite or bipartite (between labour and management with or without government involvement) process of negotiation, consultation, or exchange of information (ILO n.d.-c). The ILO requires that workers' and employers' 
organizations have the technical capacity and access to information to enable them as primary stakeholders to engage in consensus building, particularly as regards work-related social and economic issues within the ILO principles and standards. In a bipartite social dialogue, the state plays an active supporting role, establishing legal, institutional, and other frameworks that ensure productive engagement between the involved actors. Tripartism and social dialogue are significant in reconciling the parties' (as equal social partners) contending interests and addresses the imbalances in their power relations and global labour issues.

The ILO labour standards recognize the importance of human resource development through vocational guidance and training in order to improve employability and competitiveness, gain access to decent work, and increase labour productivity (ILO n.d.-d). For cruise ship service workers who are not required to have IMO certification, cruise line pre-departure and on-the-job training requirements align with the ILO standards. Interestingly, there is no emphasis at ILO on the education of seafarers about their labour rights so that they will be empowered to act on those rights and adequately protect themselves against any abuse.

The UN Office of the High Commissioner on Human Rights (OHCHR) highlights, in accordance with the 2011 United Nations Declaration on Human Rights Education and Training (UNDHRET), the importance of education and training in building values, beliefs, and attitudes that encourage individuals to understand their everyday responsibilities, uphold their rights, and contribute to the long-term prevention of human rights abuses (Office of the High Commissioner on Human Rights n.d.). Moreover, the UNDHRET stresses the role of human rights education (HRE) as a mechanism to protect the main categories of rights provided in the UN declarations and conventions, and for compliance to obligations and responsibilities outlined in these instruments (Struthers 2015). HRE is an encompassing approach that includes acquiring a basic understanding of factual human rights information and possessing a more profound knowledge of the cultural and contextual settings that present the concept and reality of human rights as an integral aspect of human life (Struthers 2015). Although the UNDHRET is non-binding soft law, it reaffirms the importance of the HRE provisions in international human rights instruments that member states are obligated to comply with. Thus, states are expected to develop a comprehensive and effective national strategy for HRE that includes the development of a curriculum on HRE in educational institutions.

An innovative aspect of UNDHRET is the tripartite framework that mandates the implementation of HRE by governments, UN organizations and agencies, and NGOs (excluding business organizations). The role of human rights NGOs in the framework is especially appropriate, because the expanded initiatives of these organizations-investigative research, policy development, and advocacy (Robinson 2004) - complement HRE. Some INGOs and NGOs engage in political activities that challenge the interest of states violating human rights treaties. NGO advocacy that names and shames offending states holds them accountable for their violations and often leads to remedies through punitive action or policy reform (Roth 2004).

The maritime ministry of faith-based INGOs and NGOs is essential in the implementation of the MLC 2006 welfare provisions and human rights guarantees. The 
strength of this mechanism is demonstrated by at least three key commitments of maritime missions and societies: (1) providing port facilities and services that promote seafarers' spiritual, physical, moral, and social welfare; (2) establishing solidarity and identification with seafarers; and (3) facilitating links with other government and private organizations committed to or essential for seafarer welfare (Mooney 2005).

\subsubsection{Corporate Mechanism}

A corporate mechanism refers to the method by which corporate entities engage in forms of self-regulation (e.g., Association of Arctic Expedition Cruise Operators), which entails changes in corporate behaviour in order to comply with public policies. Cruise shipping corporations and their crewing or manning agencies, while potentially contributing to global seafarer labour market stability, can also directly disregard labour standards and abuse seafarers' rights in the process of supplying shipping companies with cheap maritime labour (Dimitrova and Blanpain 2010). For this reason, both corporate entities are essential in the implementation of international maritime labour standards.

Corporate social responsibility (CSR) is a form of self-regulation that private businesses voluntarily perform to address public shipping regulation implementation and to improve the negative impact of shipping corporations and their supply chains to, among others, safety and quality management and transparency (YliskyläPeuralahti and Gritsenko 2014). CSR enhances performance and reputation, which are vital advantages for a highly globalized cruise shipping industry. However, two factors challenge these CSR strengths: first, the effect of CSR on financial performance, particularly on the sustainability of the company's competitive advantage and the transactional costs of compliance to the regulatory standards amid intense industry competition; and second, the nature of voluntarism in self-regulation whereby voluntary commitments are highly vulnerable to the level and extent of business actors' commitment and motivation (Vogel 2010; Yliskylä-Peuralahti and Gritsenko 2014).

\subsection{Conclusion}

Arctic cruise shipping is a booming niche segment in the growing cruise shipping industry, the most globalized sector of international shipping. The invisible seafarers who provide the tourism, travel, and hospitality services in the large luxurious hotel operations of cruise ships are beneficiaries in the cruise industry's use of Canada's Arctic for tourism. There is scant information about this smaller group of service workers other than their inclusion as part of the generic notion of seafarers on board the more popular mainstream and mega cruise ships. 
The cruise ship service workers are global seafarers in a highly globalized industry. Since cruise shipping operates within a market system governed by neoliberal policies, seafarers are treated as the crew of convenience, and their rights are not protected. Further, since the well-being of seafarers is essential for the sustainability of meeting growing passenger demand, it is necessary for the three industry actors to collectively or individually engage in the implementation of the existing international labour and human rights standards. This chapter presented a list of existing mechanisms that implement international standards.

With expedition cruise shipping growing in Canada's Arctic, research data are necessary, initially, on two problem areas: first, a profile on the global characteristics of the service workers on cruise ships with itineraries in the Canadian Arctic, and second, an assessment of the labour, employment, and social issues and the implementation of the labour and human rights standards in Canada. Additional data about the expedition cruise shipping segment will enhance the existing literature on the broader cruise ship seafarers' rights.

\section{References}

Alderton, T., \& Winchester, N. (2002). Globalisation and de-regulation in the maritime industry. Marine Policy, 26(1), 35-43. https://doi.org/10.1016/S0308-597X(01)00034-3.

Bellemare, G. (2000). End users: Actors in the industrial relations system. British Journal of International Relations, 38(3), 383-405. https://doi.org/10.1111/1467-8543.00170.

Blanck, J. I., Jr. (2006). Reflections on the negotiation of the Maritime Labor Convention 2006 at the International Labor Organization. Tulane Maritime Law Journal, 31(1), 35-55.

Bowles, P. (2008). Globalization: A taxonomy of theoretical approaches. In H. Veltmeyer (Ed.), New perspectives on globalization and antiglobalization: Prospects for a new world order? (pp. 13-33). Burlington, VT: Ashgate.

Brunnée, J. (2005). Enforcement mechanisms in international law and international environmental law. In U. Beyerlin, P.-T. Stoll, \& R. Wolfrum (Eds.), Ensuring compliance with multilateral environmental agreements: A dialogue between practitioners and academia. Boston: Martinus Nijhoff.

Chin, C. B. N. (2008a). Labour flexibilization at sea. International Feminist Journal of Politics, 10(1), 1-18. https://doi.org/10.1080/14616740701747584.

Chin, C. B. N. (2008b). Cruising in the global economy: Profits, pleasure and work at sea. Burlington: Ashgate.

Christodoulou-Varotsi, I., \& Pentsov, D. A. (2008). Maritime work law fundamentals: Responsible shipowners, reliable seafarers (1st ed.). Berlin: Springer.

Cortazzo, R. J., Jr. (2012). Development and trends of the lex maritime from international arbitration jurisprudence. Journal of Maritime Law and Commerce, 43(2), 255-277.

Dawson, J. (2018). Arctic shipping: Future prospects and ocean governance. In D. Werle, P. R. Boudreau, M. R. Brooks, M. J. A. Butler, A. Charles, S. Coffen-Smout, D. Griffiths, et al. (Eds.), The future of ocean governance and capacity development: Essays in honor of Elisabeth Mann Borgese (1918-2002) (pp. 484-489). Leiden: Brill Nijhoff.

Dawson, J., Johnston, M. E., \& Stewart, E. J. (2014). Governance of Arctic expedition cruise ships in a time of rapid environmental and economic change. Ocean and Coastal Management, 89(C), 88-99. https://doi.org/10.1016/j.ocecoaman.2013.12.005.

DeSombre, E. R. (2006). Flagging standard globalization and environmental, safety, and labor regulations at sea. Cambridge, MA: MIT Press. 
Dimitrova, D. N., \& Blanpain, R. (2010). Seafarers' rights in the globalized maritime industry. Kluwer Law International: Alphen aan den Rijn.

Equasis. (2019a). Crystal Serenity. June 11. http://www.equasis.org/EquasisWeb/restricted/ ShipInfo?fs=Search. Accessed 4 Oct 2019.

Equasis. (2019b). Fram. May 7. http://www.equasis.org/EquasisWeb/restricted/ ShipInfo?fs=Search. Accessed 4 Oct 2019.

Equasis. (2019c). Ocean Adventurer. April 30. http://www.equasis.org/EquasisWeb/restricted/ ShipInfo?fs=Search. Accessed 4 Oct 2019.

Equasis. (2019d). Ocean Endeavour. April 30. http://www.equasis.org/EquasisWeb/restricted/ ShipInfo?fs=Search. Accessed 4 Oct 2019.

Faber, S., \& Saltzman, D. (2019). Expedition cruise tips: Common regions and who sails there. Cruise Critic. January 10. https://www.cruisecritic.com/articles.cfm?ID=338. Accessed 4 Oct 2019.

Genting Hong Kong. (2015). Major transaction in relation to the acquisition of the entire equity interest in Crystal Cruises Inc. and resumption of trading. http://www.gentinghk.com/ media/1345367/e008majortransactionannouncementdated3mar15.pdf. Accessed 4 Oct 2019.

Gibson, P. (2008). Cruising in the 21st century: Who works while others play? International Journal of Hospitality Management, 27(1), 42-52. https://doi.org/10.1016/j.ijhm.2007.07.005.

Harvey, D. (2005). A brief history of neoliberalism. Oxford: Oxford University Press.

Hathaway, O. A. (2007). Why do countries commit to human rights treaties? Journal of Conflict Resolution, 51(4), 588-621. https://doi.org/10.1177/0022002707303046.

ILO (International Labour Organization). (2014). Rules of the game: A rules of the game: Brief introduction to international labour standards. Geneva: International Labour Office.

ILO. (n.d.-a). Tripartite constituents. http://www.ilo.org/global/about-the-ilo/who-we-are/tripartite-constituents/lang\%2D\%2Den/index.htm. Accessed 30 Apr 2019.

ILO. (n.d.-b). Labour legislation guidelines. http://www.ilo.org/legacy/english/dialogue/ifpdial/ llg/noframes/ch4.htm. Accessed 11 May 2019.

ILO. (n.d.-c). Social dialogue. http://www.ilo.org/ifpdial/areas-of-work/social-dialogue/ lang\%2D\%2Den/index.htm. Accessed 11 May 2019.

ILO. (n.d.-d). International labour standards on vocational guidance and training. http://ilo.org/ global/standards/subjects-covered-by-international-labour-standards/vocational-guidanceand-training/lang\%2D\%2Den/index.htm. Accessed 14 Apr 2019.

IMO (International Maritime Organization). (n.d.-a). Human element. http://www.imo.org/ OurWork/HumanElement/Pages/Default.aspx. Accessed 15 Mar 2019.

IMO. (n.d.-b). Member state audit scheme \& implementation support. http://www.imo.org/en/ OurWork/MSAS/Pages/default.aspx. Accessed 19 Mar 2019.

Innovation, Science and Economic Development Canada. (2018). Canada's tourism vision: One year of progress. Government of Canada. May 14. https://www.ic.gc.ca/eic/site/095.nsf/ eng/00007.html. Accessed 15 Mar 2019.

International Transport Workers' Federation. (n.d.). Flags of convenience. https://www.itfglobal. org/en/sector/seafarers/flags-of-convenience. Accessed 10 May 2019.

Jarvis, H. (2017). Expedition cruise market in growth trend. Standby Nordic, June 7. https://standbynordic.com/expedition-cruise-market-in-growth-trend/. Accessed 4 Oct 2019.

Knudsen, O. F., \& Hassler, B. (2011). IMO legislation and its implementation: Accident risk, vessel deficiencies and national administrative practices. Marine Policy, 35(2), 201-207. https:// doi.org/10.1016/j.marpol.2010.09.006.

Lajeunesse, A. (2012). A new Mediterranean? Arctic shipping prospects for the 21st century. Journal of Maritime Law and Commerce, 43(4), 521-527.

Lilie, N. (2008). The ILO Maritime Labour Convention, 2006: A new paradigm for global labour rights implementation. In K. Papadakis (Ed.), Cross-border social dialogue and agreements: An emerging global industrial relations framework? (pp. 191-217). Geneva: International Institute for Labour Studies. 
Manley, B., Elliot, S., \& Jacobs, S. (2017). Expedition cruising in the Canadian Arctic: Visitor motives and the influence of education programming on knowledge, attitudes, and behaviours. Resources, 6(3), 23. https://doi.org/10.3390/resources6030023.

maribus gGmbH. (2010). Global shipping: A dynamic market. In World Ocean Review 1 (pp. 164-171). Hamburg: maribus gGmbH.

Mathisen, M. 2019. Expedition cruise market: 8,500 new berths. Cruise Industry News, May 15. https://www.cruiseindustrynews.com/cruise-news/20851-expedition-cruise-market8-500-new-berths.html. Accessed 4 Oct 2019.

Mazmanian, D. A., \& Sabatier, P. A. (1989). Implementation and public policy. Lanham: University Press of America.

McConnell, M. L., Devlin, D., \& Doumbia-Henry, C. (2011). The Maritime Labour Convention, 2006: A legal primer to an emerging international regime. Boston: Martinus Nijhoff.

McDorman, T. L. (2000). Regional port state control agreements: Some issues of international law. Ocean and Coastal Law Journal, 5(2), 207-225.

MLC. (2006). Maritime Labour Convention (23 February 2006, entered into force 20 August 2013), 45 ILM 792 (2006).

Mooney, P. C. (2005). Maritime mission: History, developments, a new perspective. Zoetermeer: Uitgeverij Boekencentrum.

Mukherjee, P. K., \& Brownrigg, M. (2013). Farthing on international shipping (4th ed.). Berlin: Springer.

Office of the High Commissioner on Human Rights. (n.d.). Human rights education and training. http://www.ohchr.org/EN/Issues/Education/Training/Pages/HREducationTrainingIndex.aspx. Accessed 14 May 2019.

Piniella, F., Silos, J. M., \& Bernal, F. (2013). Who will give effect to the ILO's Maritime Labour Convention, 2006? International Labour Review, 152(1), 59-83. https://doi. org/10.1111/j.1564-913X.2013.00169.x.

Politakis, G. (2013). Bringing the human element to the forefront: The ILO's Maritime Labour Convention, 2006 ready to sail. Aegean Review of the Law of the Sea and Maritime Law, 2(1), 37-51. https://doi.org/10.1007/s12180-013-0024-y.

Ratner, S. R. (2001). Corporations and human rights: A theory of legal responsibility. The Yale Law Journal, 111(3), 443-545. https://doi.org/10.2307/797542.

Robinson, M. (2004). Advancing economic, social, and cultural rights: The way forward. Human Rights Quarterly, 26(4), 866-872.

Rodrigue, J.-P., \& Notteboom, T. (2013). The geography of cruises: Itineraries, not destinations. Applied Geography, 38, 31-42.

Roth, K. (2004). Defending economic, social and cultural rights: Practical issues faced by an international human rights organization. Human Rights Quarterly, 26(1), 63-73. https://doi. org/10.1353/hrq.2004.0010.

Satterlund, T. D., Lee, J. P., Moore, R. S., \& Antin, T. M. J. (2009). Challenges to implementing and enforcing California's smoke-free workplace act in bars. Drugs: Education, Prevention and Policy, 16(5), 422-435. https://doi.org/10.1080/09687630802302872.

Scholte, J. A. (2005). The sources of neoliberal globalization (Overarching concerns program paper number 8). United Nations Research Institute for Social Development. http://www. unrisd.org/80256B3C005BCCF9/httpNetITFramePDF?ReadForm\&parentunid=9E1C54CE EB19A314C12570B4004D0881\& parentdoctype $=$ paper\&netitpath $=80256 \mathrm{~B} 3 \mathrm{C005BCCF9/}$ (httpAuxPages)/9E1C54CEEB19A314C12570B4004D0881/\$file/scholte.pdf. Accessed 27 Apr 2018.

Seafarers' Rights International. (2016). Seafarers have human rights under international law. http://seafarersrights.org/seafarers-subjects/human-rights/. Accessed 28 May 2019.

Smith, V. L. (2006). Adventure cruising: An ethnography of small ship travel. In R. K. Dowling (Ed.), Cruise ship tourism (pp. 240-250). Wallingford: CABI Pubishing.

Smith, R. K. M. (2009). Human rights in international law. In M. Goodhart (Ed.), Human rights politics and practice (pp. 60-76). New York: Oxford University Press. 
Ssenyonjo, M. (2009). Economic, social and cultural rights in international law. Portland: Hart Publishing.

Strange, S. (1996). The retreat of the state: The diffusion of power in the world economy. New York: Cambridge University Press.

Struthers, A. (2015). Human rights education: Educating about, through and for human rights. International Journal of Human Rights, 19(1), 53-73. https://doi.org/10.1080/1364298 7.2014.986652.

Terry, W. C. (2011). Geographic limits to global labor market flexibility: The human resources paradox of the cruise industry. Geoforum, 42(6), 660-670. https://doi.org/10.1016/j. geoforum.2011.06.006.

The Maritime Executive. (2017). New Crystal ship for Northwest Passage. The Maritime Executive, 1 October. https://www.maritime-executive.com/article/new-crystal-ship-for-northwest-passage\#gs.vYyorog. Accessed 4 Oct 2019.

Tolofari, S., Button, K., \& Pitfield, D. (1986). Shipping costs and the controversy over open registry. The Journal of Industrial Economics, 34(4), 409-427. https://doi.org/10.2307/2098626.

van Boven, T. C. (1982). Distinguishing criteria of human rights. In K. Vasak \& P. Alston (Eds.), The international dimensions of human rights (pp. 43-59). Paris: UNESCO.

Vasak, K. (1977). A 30-year struggle: The sustained efforts to give force of law to the Universal Declaration. The UNESCO Courier, 29 November.

Vasak, K. (1982). The distinguishing criteria of institutions. In K. Vasak \& P. Alston (Eds.), The international dimensions of human rights (pp. 215-228). Paris: UNESCO.

Véronneau, S., \& Roy, J. (2009). Global service supply chains: An empirical study of current practices and challenges of a cruise line corporation. Tourism Management, 30(1), 128-139. https:// doi.org/10.1016/j.tourman.2008.05.008.

Vogel, D. (2010). The private regulation of global corporate conduct: Achievements and limitations. Business \& Society, 49(1), 68-87. https://doi.org/10.1177/0007650309343407.

Walker, J. (2016). Seven ways cruise lines are screwing crew members. Cruise Law News, 26 June. https://www.cruiselawnews.com/2016/06/articles/crew-member-rights/seven-ways-cruiselines-are-screwing-crew-members/. Accessed 4 Oct 2019.

Walker, K., \& Moscardo, G. (2006). The impact of interpretation on passengers of expedition cruises. In R. K. Dowling (Ed.), Cruise ship tourism (pp. 105-114). Wallingford: CABI Publishing.

Weaver, A., \& Duval, D. T. (2008). International and transnational aspects of the global cruise industry. In T. Coles \& C. Michael Hall (Eds.), International business and tourism: Global issues, contemporary interactions (pp. 106-123). London: Routledge.

Williams, D. M., \& Armstrong, J. (2010). Technological advances in the maritime sector: Some implications for trade, modernization, and the process of globalization in the nineteenth century. In M. Fusaro \& A. Polonia (Eds.), Maritime history as global history (pp. 177-202). St. John's: International Maritime Economic History Association.

Wind Rose Network. (n.d.). The cruise industry: General analysis and overview. http://www. windrosenetwork.com/The-Cruise-Industry-General-Analysis-and-Overview. Accessed 27 Apr 2019.

Wood, R. E. (2000). Caribbean cruise tourism: Globalization at sea. Annals of Tourism Research, 27(2), 345-370. https://doi.org/10.1016/S0160-7383(99)00073-0.

Wood, R. E. (2006). Cruise tourism: A paradigmatic case of globalization. In R. K. Dowling (Ed.), Cruise ship tourism (pp. 397-406). Wallingford: CABI Publishing.

Yliskylä-Peuralahti, J., \& Gritsenko, D. (2014). Binding rules or voluntary actions? A conceptual framework for CSR in shipping. WMU Journal of Maritime Affairs, 13(2), 251-268. https:// doi.org/10.1007/s13437-014-0059-8. 
Open Access This chapter is licensed under the terms of the Creative Commons Attribution 4.0 International License (http://creativecommons.org/licenses/by/4.0/), which permits use, sharing, adaptation, distribution and reproduction in any medium or format, as long as you give appropriate credit to the original author(s) and the source, provide a link to the Creative Commons license and indicate if changes were made.

The images or other third party material in this chapter are included in the chapter's Creative Commons license, unless indicated otherwise in a credit line to the material. If material is not included in the chapter's Creative Commons license and your intended use is not permitted by statutory regulation or exceeds the permitted use, you will need to obtain permission directly from the copyright holder. 